\title{
Nursing and light technologies for a peace culture within the family
}

\author{
Enfermagem e tecnologias leves para a cultura de paz na família \\ Enfermería y tecnologías ligeras para la cultura de paz en la familia
}

\begin{abstract}
Hugo Fernandes', Ana Lúcia de Moraes Horta'
'Universidade Federal de São Paulo, School of Nursing of São Paulo, Department of Collective Health. São Paulo, São Paulo, Brazil.
\end{abstract}

How to cite this article:

Fernandes H, Horta ALM. Nursing and light technologies for a peace culture within the family.

Rev Bras Enferm [Internet]. 2018;71(Suppl 6):2854-7. [Thematic Issue: Good practices in the care process as the centrality of the Nursing] DOI: http://dx.doi.org/10.1590/0034-7167-2017-0756

\section{Submission: 09-10-2017_Approval: 05-23-2018}

\begin{abstract}
Objective: To reflect on technologies for the peace culture that can be used in family nursing. Method: Theoretical essay, based on the premises of non-violence and peace culture. Results: Four light technologies are singled out for the peace culture within families: nonviolent communication, qualified listening, conflict mediation, and restorative circles. Conclusion: The technologies proposed can be used by nurses to promote care and policies aiming at a peace culture and non-violence in families, with the objective of assisting in the obtainment of the well-being for family systems and their correlations.
\end{abstract}

Descriptors: Nursing; Family Nursing; Violence; Technology; Communication.

\section{RESUMO}

Objetivo: Refletir sobre tecnologias para a cultura de paz que possam ser usadas pela enfermagem de família. Método: Ensaio teórico fundamentado nas premissas da cultura de paz e não violência. Resultados: Apontam-se quatro tecnologias leves para a cultura de paz nas famílias: comunicação não violenta, escuta qualificada, mediação de conflitos e círculos restaurativos. Conclusão: As tecnologias apontadas podem ser empregadas por enfermeiros para promover cuidados e políticas voltadas à cultura de paz e não violência nas famílias, com o objetivo de auxiliar na obtenção de bem-estar do sistema familiar e de sistemas correlatos.

Descritores: Enfermagem; Enfermagem Familiar; Violência; Tecnologia; Comunicação.

\section{RESUMEN}

Objetivo: Reflexionar sobre tecnologías para la cultura de paz que puedan ser usadas por la enfermería de la familia. Método: Ensayo teórico fundamentado en las premisas de la cultura de paz y de la no violencia. Resultados: Se señalan cuatro tecnologías ligeras para la cultura de paz en las familias: la comunicación no violenta, la escucha calificada, la mediación de conflictos y los círculos restaurativos. Conclusión: Las tecnologías apuntadas pueden ser empleadas por enfermeros para promover los cuidados y las políticas dirigidas a la cultura de paz y de la no violencia en las familias, con el objetivo de ayudarlas en la obtención de bienestar del sistema familiar y de los sistemas relacionados.

Descriptores: Enfermería; Enfermería de la Familia; Violencia; Tecnología; Comunicación. 


\section{INTRODUCTION}

The violent impulse is not a constant among humans but a condition that may be precipitated by numerous social, emotional, physical, and behavioral factors. Avoiding such impulse is a desire of most people in different cultures and societies. Violence may arise in several situations, including in family relationships, causing suffering and negative modifications in families, weakening relationships, and breaking ties ${ }^{(1)}$.

Violent situations can be perpetrated through many generations when the family tends to naturalize them or when it fails to clearly understand their deleterious effects on the members involved, both victims or attackers. Therefore, violence affects the family system and the daily life of its members, whether men, women, children or older adults. The life cycle can be influenced by it, as well as the composition of affections and the organization of the institution.

We understand family violence as aggression (physical, emotional, verbal, sexual), negligence, or intentional omission by individuals with a family bond to the victim (natural, civil, social, or substitute kinship) aimed at offending, benefitting or taking advantage, demoralizing, oppressing, or triggering pain and suffering to whom the offender regards as an inferior. Thus, family violence is closely related to the idea of power relations.

The attributes of a peace culture proposed by the United Nations Educational, Scientific and Cultural Organization $(\text { UNESCO })^{(2)}$ arise as mechanisms to minimize the violence and its repercussions in several systems, including the family, in search of an harmonious coexistence between peoples and societies. Its proposal is that everyone, including families, transcends individual values and uses the following assumptions to achieve the desired homeostasis: love for the other, compassion, solidarity, cooperation, humility, freedom, and responsibility.

During family care, when they come across evidence of violence, the nurse(s) must treat them in a technical and scientific manner but also with humanity, taking the appropriate measures for the full care to people in situations of violence, such as case notification (suspected or confirmed), referral to specialized services, protection of the victim, coordination of intersectoral measures, and networking. However, the nurse(s) should not care only for those who are suffering but also for the aggressor and all family members directly or indirectly involved, trying to understand contexts and factors involved in triggering the violent drive, as the symptoms and signs presented by one person may be mere indicators of deeper or branchy issues. Therefore, these professionals need to have a more systemic standpoint, devoid of immediate judgment ${ }^{(3-4)}$.

Nurses have many tools that can assist them in this care, such as the light technologies. They are so called because they do not involve the use of sophisticated physical or mechanical apparatuses. Light technologies aim at the relationships and the creation of bonds, the protection and valuation of subjectivities, which cannot be treated with the other technologies - the hard or light-hard ones ${ }^{(5)}$.

In a cohesive nursing care, the use of "technologies for a peace culture" can be included in dealing with families experiencing violence or who want to avoid it. Searches in online databases evidenced gaps on the subject, which is still emerging.
The few evidence available singles out technologies easy to implement by nursing, but infrequent in curricula ${ }^{(6-7)}$. Such technologies are presented on the following pages.

Based on the UNESCO peace culture premises ${ }^{(2)}$, we propose the following question: Which technologies may the nurses use in their routine to promote the peace culture in families? The goal here is, therefore, to reflect on technologies for the peace culture that can be used in family nursing.

We chose to present this study as a theoretical text due to the possibility of exposing ideas and criticism in a fluent and flexible manner, considering the subjectivity in the ways of thinking, feeling, and acting when it comes to the topics discussed. From the arguments, the possibility of using the following successful technologies for the peace culture in families ${ }^{(6-10)}$ is unveiled: nonviolent communication, qualified listening, conflict mediation, and restorative circles.

\section{NONVIOLENT COMMUNICATION}

Communication is a necessity for the circulation of information and construction of ideas. Families use this tool in their everyday lives, but not always realize its form, content, medium, and manner.

The transmission of thought may be verbal and non-verbal. Both are commonly used by families, depending on which message one intends to convey, and are intimately influenced by the relationships among the family members. Families often create very particular communication mechanisms (such as looks, gestures, and symbols) to which the nurse must be aware, requesting explanations when they fail to understand them.

In addition, noises in communication can be frequent in families dealing with violence. In many situations, the expressions, phrases, gestures, and other kinds of language have a great violent appeal, causing injuries to the family system and resonance in other correlated systems (school, work, religion etc.). Thus, it is interesting to value the nonviolent communication as a care technology, since it seeks to facilitate the understandable, firm, and safe dialogue, causing the least possible negative feelings in everyone involved. It is proposed that nurses seek changes in focus, switching from the descriptions of "errors" of one or others to the "needs" of all, increase the cooperation, and reduce destructive criticisms or words of suffering exchanged in an excruciating way.

Nonviolent communication has some components that must be considered in the family care, namely: (1) Observation without judgment: every time one intends to judge the violent behavior of someone or the submission of another, without understanding the depth of the context in which the message was generated, there is a probability of driving a biased care. (2) Understand what are feelings and "non-feelings": the use of the verb "to feel" is very common in situations where it does not represents what in fact is. The expression of feelings within the family should be valued, but distinguishing actions, thoughts, and beliefs that have nothing to do with what they really feel or what touches the soul. It is also interesting that understandings on the self-responsibility for their feelings are encouraged. (3) Identification of needs: we start from the idea that there is no dysfunctional family but that, at certain times, the family may not know how to maintain peace and harmony, finding difficulty 
in maintaining the roles of members and their balance. Faced with difficult-to-solve problems, an aggressive communication may be a mechanism to "forcibly" re-establish the homeostasis. (4) Asking for what really matters: an exercise to be proposed to all people is asking clearly what they really want from the other(s). The clarity of the request can minimize suffering and frustrations of those who emit and receive information. This occurs because not always all those involved understand "indirect" or subtle forms of non-verbal communication. It is suggested the use of statements that reveal the needs of who is speaking and not those that blame the other ${ }^{(7)}$.

Nonviolent communication should value the family elements in an egalitarian, simple, and safe form, in favor of collective goals; facilitate the communication with people regarded as "difficult" or "challenging;" improve the understanding of the behavior of others, and avoid personal attacks. In addition, it is interesting that all those involved help in finding and implementing actions to solve conflicts. In short, building together aids the search for family peace and creates a cooperative environment ${ }^{(7)}$.

\section{QUALIFIED LISTENING}

The qualified listening transcends the act of listening, allowing the understanding of difficulties, feelings, and sorrows of the other from the understanding of what is being experienced. It is an instrument that must be used by the nurse in their daily routine, as it facilitates the development of subject and family autonomy and allows the protection in a more significant level, possibly transforming pain scenarios through the creation of trust relations within the nurse-user-family circle, "giving voice" to what they feel ${ }^{(8)}$.

One of the main tools of qualified listening is empathy, which gives meaning to relations. Users and families realize when the qualified listening is being employed in an empathetic manner, emphasizing feelings of trust, patience, non-recrimination, confidentiality, and security. In some cases, the qualified listening enhances treatments and therapeutic projects.

Listening and dialogue are not gifts or innate abilities; they can be developed by the search for information, the daily practice of "listening" carefully to what the other speaks, and by enhancing non-selective listening skills, asking open questions, paraphrasing the content of the conversation, reporting concerns, and synthesizing the information told ${ }^{(8)}$.

\section{RESTORATIVE CIRCLES}

Coming from the judiciary system, restorative practices have often been applied to assist people and groups to deal with conflicts (usually criminal ones) through dialogue, integration, coexistence, and respect. Such practices come from premises of restorative justice, according to which it is expected that violence situations can be minimized through dialogue. The decision-making process is conducted in a participatory way and should involve all elements. All this is in accordance with a new paradigm of understanding violence, based on the positive expectation. To sum that up, the focus is not the problem itself, but the proposals of solution that are created jointly ${ }^{(9)}$.
Restorative practices in health have emerged as a primary care instrument to prevent the violence that compromises the quality of life within a community, organization, or family. One of the most common forms of these practices are the restorative circles, in which people are gathered in small groups (up to ten individuals, including a facilitator), comfortably arranged in a circle. Playful elements are often used, such as toys, small objects, or colored materials that may initiate the narratives and expressions of feelings. All those who are present must have an equal opportunity to express themselves and should not participate in an authoritative manner. Information confidentiality must be respect, even for those that are expressed in a non-verbal way.

The nurse can be a facilitator of the restorative circle, urging families and individuals to acknowledge their responsibility for their acts and the consequences generated by them. Those involved learn to help themselves and, consequently, to help others, including those who are not part of this circle, such as friends, distant family members, and co-workers, through ideas and solution generated in the group to find positive alternatives to everyone's life. It is interesting that the facilitator takes note of ideas presented and return them to the group whenever there is an opportunity.

\section{CONFLICT MEDIATION}

Conflicts, antagonizing ideas, and disagreements are not harmful to families, since they may represent possibilities to understand different and complementary ways of thinking and acting. Such situations are particularities of humanity since people need a friendly environment and an external party to mediate their conflicts, broadening narratives and facilitating the encounter. Furthermore, these situations create new possibilities for the communication to occur in the most effective way. The nurse can be the conflict mediator in families, considering characteristics such as impartiality, independence, and the participatory action of all of those involved. In addition, the mediator must remain vigilant, avoid judgments or arbitrary postures, seek to know the nature of the conflicts and keep the confidentiality of information given throughout the mediation ${ }^{(10)}$.

The family accepting any mediation procedure demonstrates a positive aspect: the search for minimally satisfactory solutions to all those involved, to enable agreements or improvements in existing relationships.

One of the ways to operationalize the conflict mediation if systematizing it in a procedural manner. That is, dividing it in moments here called (1) definition and listening; (2) clarification and synthesis; (3) searching for solutions and closing deals. In the first moment, the nurse-mediator should clarify how the mediation process will happen and establish rules and conducts to maintain some order and respect, ensuring the listening and expression of all those involved. Then, they must ask the mediated people to talk about the conflict. The decision on who initiates the talk is of those involved, not of the nurse. However, it is important that the equality is respected in the narratives. In the case of a discrepant domination of the conversation, the nurse must seek a balance among the mediated individuals. In the second moment, it is suggested that the nurse sums up the facts presented and asks those involved 
to correct inconsistencies. Also, they should to raise points of convergence of the narratives to draft resolutions for the conflict. Thus, at this stage, some feelings can be exacerbated and aggressive expressions may occur, damaging the communication. The nurse should remain attentive to this and remind the group of the initial rules, trying to calm down the moods. In extreme cases, the mediation may be interrupted or held in a private session, so that the needs of each one become clear. Finally, in the third moment, it is recommended that the nurse inquires the mediated people on the possible and rational ways to solve the conflicts. It should be noted: the mediator must not induce solutions, just stimulate the communication for them to emerge. Caveats mentioned should also be respected. Once the parties deem the possibilities as plausible, the recommended is that the mediator uses some form of affirmation of the agreement.
If applicable, it is even possible to sign a text devised by those involved as a way of securing the agreement ${ }^{(10)}$.

\section{CONCLUSION}

The limitation of this essay is the fact that it sticks to technologies for the peace culture within families and their possible use by Nursing, not addressing hard and light-hard technologies and interdisciplinary health care. However, the knowledge on the technologies mentioned assists the planning and implementation of positive care in families who wish to walk towards peace and collective well-being.

Premises for a peace culture seek a better world (without utopias) through the use of practical tools and implementation of humanitarian values in everyday life, converging with family nursing practices.

\section{REFERENCES}

1. Friend DJ, Bradley RPC, Gottman JM. Displayed affective behavior intimate partner violence types during non-violent conflict discussions. J Fam Viol[Internet]. 2016[cited 2017 Mar 12];32(5):493-04. Available from: https://link.springer.com/content/ pdf/10.1007\%2Fs10896-016-9870-7.pdf

2. Organização das Nações Unidas para Educação, Ciência e Cultura-UNESCO. Cultura de Paz no Brasil [Internet]. 2017 [cited 2017 Feb 15]. Available from: http://www.unesco.org/new/pt/brasilia/social-and-human-sciences/culture-of-peace

3. Cruz RAO, Araujo ELM, Nascimento NM, Lima RJ, França JRFS, Oliveira JS. Reflections in the light of the complexity theory and nursing education. Rev Bras Enferm[Internet]. 2017[cited 2017 Jul 5];70(1):236-9. Available from: http://www.scielo.br/pdf/reben/ v70n1/en_0034-7167-reben-70-01-0236.pdf

4. Silva RMCRA, Oliveira DC, Pereira ER. The discursive production of professionals about humanizing health: singularity, rights and ethics. Rev Latino-Am Enfermagem[Internet]. 2015[cited 2017 Jun 2];23(5):936-44. Available from: http://www.scielo.br/pdf/rlae/ v23n5/0104-1169-rlae-23-05-00936.pdf

5. Horta NC, Capobiango M. Novas tecnologias: desafio e perspectivas na saúde. Perc Acad[Internet]. 2016[cited 2017 Jun 8];6(11):69. Available from: http://periodicos.pucminas.br/index.php/percursoacademico/article/view/14505/11807

6. Barash DP, Webel CP. Peace \& Conflict Studies. 4 ed. California: SAGE; 2018

7. Rosenberg M. Nonviolent communication: a language of life. 3 ed. California: Puddle Dancer; 2015.

8. Maynart WHC, Albuquerque MCS, Brêda MZ, Jorge JS. Qualified listening and embracement in psychosocial care. Acta Paul Enferm[Internet]. 2014[cited 2017 Jun 7];27(4):300-3. Available from: http://www.scielo.br/pdf/ape/v27n4/en_1982-0194ape-027-004-0300.pdf

9. Ferrão IS, Santos SS, Dias ACG. Psicologia e Práticas Restaurativas na Socioeducação: relato de experiência. Psicol Ciênc Prof[Internet]. 2016[cited 2017 Jun 8];36(2):354-63. Available from: http://www.scielo.br/pdf/pcp/v36n2/1982-3703-pcp-36-2-0354.pdf

10. Feijó MR, Stelata PL, Toledo M, Bonduki L, Chiareto A, Ciasca D, et al. A construção de um projeto de mediação de conflitos e de cultura de paz: etapas e desafios. Nova Perspec Sistêm[Internet]. 2011[cited 2017 Aug 28];20(40):83-98. Available from: http:// revistanps.com.br/index.php/nps/article/viewFile/86/199 